\title{
Morphometric and genetic variations of species composers of nike fish assemblages in Gorontalo Bay Waters, Indonesia
}

\author{
FEMY M. SAHAMI ${ }^{1, \vartheta}$, RENE CHARLES KEPEL ${ }^{2}$, ABDUL HAFIDZ OLII ${ }^{1}$, SILVESTER BENNY PRATASIK $^{2}$, \\ RIDWAN LASABUDA ${ }^{2}$, ADNAN WANTASEN ${ }^{2}$, SITTY AINSYAH HABIBIE ${ }^{1}$ \\ ${ }^{1}$ Faculty of Fisheries and Marine Sciences, Universitas Negeri Gorontalo. Jl. Jend. Sudirman No. 6, Gorontalo City 96128 , Gorontalo, Indonesia. \\ Tel.: +62-435-821125, Fax.: +62-435-821752. `email: femysahami@ung.ac.id \\ ${ }^{2}$ Faculty of Fisheries and Marine Sciences, Universitas Sam Ratulangi. Jl. Kleak Bahu, Manado 95115, North Sulawesi, Indonesia
}

Manuscript received: 13 July 2020. Revision accepted: 11 September 2020.

\begin{abstract}
Sahami FM, Kepel RC, Olii AH, Pratasik SB, Lasabuda R, Wantasen A, Habibie SA. 2020. Morphometric and genetic variations of species composers of nike fish assemblages in Gorontalo Bay Waters, Indonesia. Biodiversitas 21: 4571-4581. Nike is Gobioidei fish at the post-larval and juvenile stages whose habitat is still in seawater before they migrate to the freshwater, grow up, and spawn to fulfill their life cycle as an amphidromous species. This study aims to identify the species composers of Nike fish in Gorontalo Bay waters based on their morphometric and molecular characters. 2,523 samples were collected from the catches of fishermen during three periods of their appearance in Gorontalo Bay waters from January to March 2019. The samples were grouped based on their similarity of melanophore patterns, and morphometric characters of 10 units were then measured. This study found 20 different groups of melanophore patterns; 15 of them were new melanophore patterns. DNA samples from each group of new melanophore patterns were then isolated for molecular analysis. The morphometric analysis grouped the 20 melanophore patterns into three separate clusters that were confirmed through molecular analysis. The results of Gen Cytochrome Oxidase I (COI) sequences indicate that the new melanophore patterns of Nike fish assemblages consisting of six species; five species in the Gobiidae family (i.e. Sicyopterus parvei, S. cynocephalus, S. longifilis, S. lagocephalus, and Stiphodon semoni) and a species in the Eleotridae family (Belobranchus belobranchus).
\end{abstract}

Keywords: Amphidromous, COI gene, Eleotridae, Gobiidae, molecular

\section{INTRODUCTION}

Nike (local name) is a designation for a goby fish group in the post-larval to the juvenile stages that seasonally appear in Gorontalo Bay waters, usually in the last quarter moon phase towards the new moon. The people of Gorontalo catch this fish for consumption as well as in other areas, such as Nike in North Sulawesi (Pangemanan et al. 2020), Penja in West Sulawesi (Nurjirana et al. 2019a; Nurjirana et al. 2019b), and Dulong by the Philippines (Thomas et al. 2013). As a group of amphidromous fish, the catching is usually done when they migrate from the sea to the river. Keith (2003); Yamasaki et al. (2011); Taillebois et al. (2012); and Mennesson et al. (2019) mention that adult amphidromous fish will spawn in freshwater, the eggs are placed on the substrate at the bottom of the water, and the larvae are then carried away by the estuary area into the sea. After the larvae live in the sea, they will then return to the river at the post-larval and juvenile stages. Olii et al. (2017) and Pasisingi and Abdullah (2018) report that Nike fish in Gorontalo Bay will first appear in the sea and move closer to the estuary areas by time until they finally disappear.

The local communities and general public believe Nike fish as a single species. Usman (2016) reported that Gorontalo Nike fish has been identified as Awaous melanocephalus Bleeker 1849. Furthermore, Olii et al. (2019) reported that Nike fish is Sicyopterus longifilis de Beaufort 1912. Several studies were then conducted to investigate reality. Sahami et al. (2019b), in her recent study, reported that the composers of Nike fish assemblages in Gorontalo Bay consist of four species (i.e. Sicyopterus pugnans Ogilvie-Grant 1884, Sicyopterus cynocephalus Valenciennes 1837, Bunaka gyrinoides Bleeker 1853, and Belobranchus segura Keith, Hadiaty and Lord 2012). Meanwhile, Nurjirana et al. (2019b) also found similar findings that Nike fish is composed of species in the Gobiidae and Eleotridae family. However, limited studies reported the diversity of similar fish assemblages in other aquatic areas. Nurjirana et al. (2019a) reported Penja fish in West Sulawesi consisting of six genera and nine species (i.e. Sicyopterus lagocephalus Pallas 1770, Sicyopterus longifilis, Stiphodon semoni Weber 1895, Stiphodon atropurpureus Herre 1927, Sicyopus zosterophorum Bleeker 1856, Smilosicyopus leprurus Sakai and Nakamura 1979, Schismatogobius sp., Eleotris fusca Forster 1801, and Eleotris sp.). Furthemore, Pangemanan et al. (2020) reported Nike fish in Tondano Lake to consist of six different melanophore patterns that belong to the same species Ophioleotris aporos.

The popularity of Nike fish, which is much favored by the community and its high economic value, has a significant impact on the high level of fishing. However, scientific studies on these fish in bioecological, fishing, and economic are still limited. It is feared that limited information and uncontrolled fishing will reduce diversity if no rapid and appropriate management is carried out. As an initial step, research related to the morphometric and 
molecular variations of the species that make up the Nike fish assemblage is critical to finding out the bioecological information of species. This particular information can be used as a basis for its sustainable management. Generally, research on the morphometric and molecular of Nike fish in Gorontalo has never been conducted. The morphometric and molecular data of the composers of Nike fish are crucial to validate the taxonomic status. These data are often combined to overcome the limitations of the morphological identification which heavily influenced by the environment (Firawati et al. 2017; Habibie et al. 2018). Because the determination of juvenile gobies down to the species level based on morphological characters is difficult to be carried out (Yokoo et al. 2011), Also, melanophores can be found in newly hatched gobies larvae (Yamasaki et al. 2011), Hence this study using a grouping strategy based on the similarity of the melanophore patterns. This study aims to identify the species composers of Nike fish assemblages in Gorontalo Bay based on morphometric and molecular characters.

\section{MATERIALS AND METHODS}

\section{Sampling}

The samples were obtained from the catches of fishermen during the three occurrence periods (i.e. January-March 2019) in Gorontalo Bay to the estuary of Bone Bolango River (Figure 1). The sampling was carried out from the first day until the last day in each appearance period. The sampled fishes were temporarily preserved in an icebox $\left(4^{\circ} \mathrm{C}\right)$ and were transported to the laboratory for further analysis. The morphology of the Nike fish is recognized by the morphological features described by Olii et al. (2019) and Pasisingi et al. (2020a). The sample grouping referred to the initial method used by Sahami et al. (2019b) based on the differences in melanophore patterns in the body. 20 groups of sample were found in this study, in which 15 groups were new melanophore patterns and coded with N6-N20, while five groups (N1N5) were the melanophore patterns that had been reported Sahami et al. (2019b). The measurement of morphometric characters was carried out on 20 groups of melanophore patterns, whereas the samples for molecular analysis were only obtained from 15 samples of newly discovered melanophore patterns. Immediately after the measurement of morphometric characters, five individuals were taken from each group and each of them was then placed in a sample bottle and added with $95 \%$ ethanol solution for molecular analysis.

\section{Morphometric characters}

The morphometric characters of Nike fish consist of 10 characters modified from Benbow et al. (2004) (Figure 2 and Table 1). The ten characters were chosen because they are easily observable parts of the body, while the other body parts are still not fully developed. The measurement was performed using Image-J application.

Pasisingi et al. (2020a) stated that Nike fish population shows a positive allometric growth pattern. Therefore, each measured morphometric character data was then standardized by following the allometric formula according to Elliott et al. (1995) as follows:

$$
\mathrm{M}_{\mathrm{adj}}=\mathrm{M}\left(\mathrm{L}_{\mathrm{s}} / \mathrm{L}_{0}\right)^{\mathrm{b}}
$$

$\mathbf{M}_{\mathrm{adj}}$ is the standardized morphometric data, $\mathbf{M}$ is the measured morphometric data, $\mathrm{L}_{0}$ is the total length of fish, $\mathrm{L}_{\mathrm{s}}$ is the average total length, and parameter $\mathrm{b}$ is the slope of $\log$-linear curve $\mathrm{M}$ to $\log \mathrm{L}_{0}$ of all data.

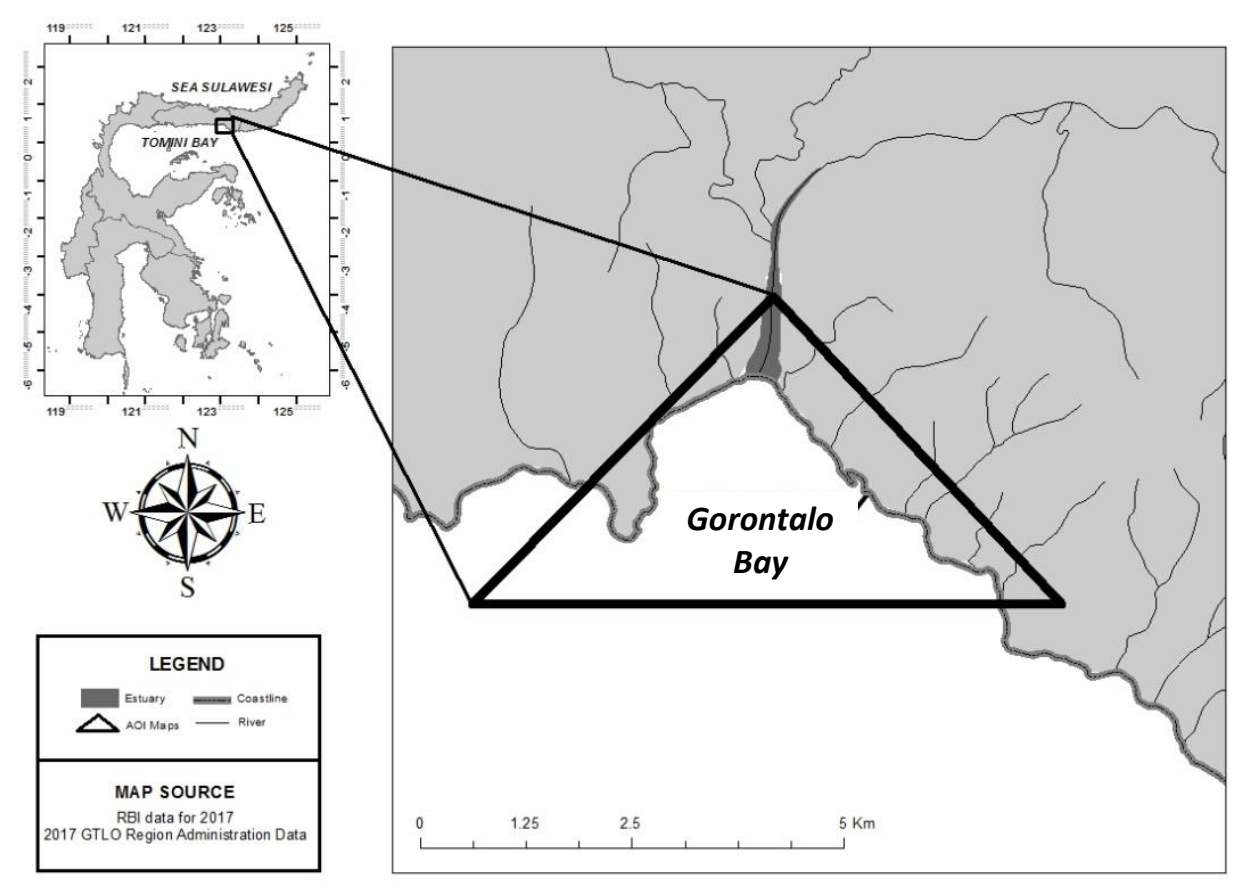

Figure 1. Map of the research location in Gorontalo Bay Waters, Gorontalo Province, Indonesia 


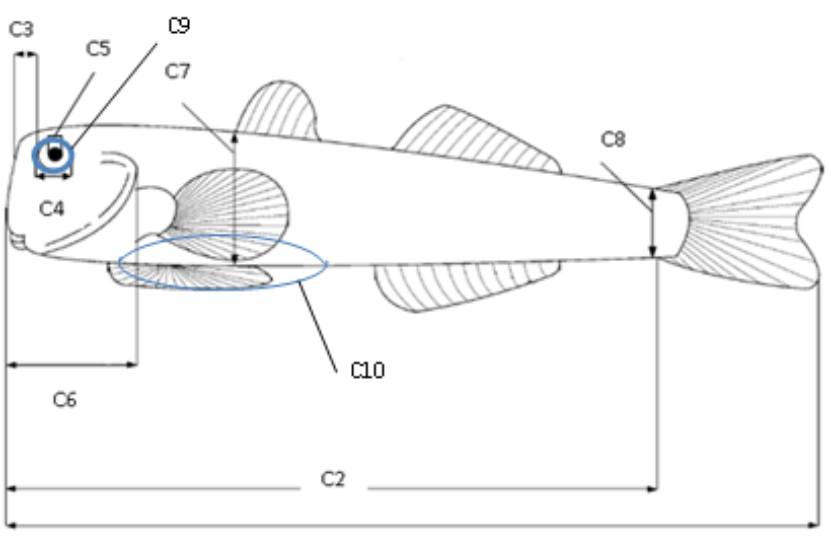

$\mathrm{Cl}$

Figure 2. Morphometric characters of Nike fish (modified from Benbow et al. 2004)

Table 1. Morphometric characters of Nike fish (modified from Benbow et al. 2004)

\begin{tabular}{|c|c|c|c|}
\hline No. & $\begin{array}{l}\text { Morphometric } \\
\text { characters }\end{array}$ & No. & $\begin{array}{l}\text { Morphometric } \\
\text { characters }\end{array}$ \\
\hline $\mathrm{C} 1$ & Total Length (TL) & C6 & Head Length $(H L)$ \\
\hline $\mathrm{C} 2$ & Standard Length (SL) & $\mathrm{C} 7$ & Body Depth (BD) \\
\hline $\mathrm{C} 3$ & Preorbital Length (PL) & $\mathrm{C} 8$ & Peduncle Depth (PD) \\
\hline $\mathrm{C} 4$ & Eye Diameter (ED) & C9 & Eye Area (EA) \\
\hline $\mathrm{C} 5$ & Eye Pupil Diameter (EP) & $\mathrm{C} 10$ & Yolk Sac area (YS) \\
\hline
\end{tabular}

\section{DNA extraction, PCR amplification, and sequencing}

Molecular analysis was carried out through several stages including collection of fish tissue, Deoxyribonucleic acid (DNA) extraction, Polymerase Chain Reaction (PCR) DNA, electrophoresis, and DNA sequencing. The DNA was extracted using Genomic DNA Mini Kit Tissue by following the protocol of the kit. Approximately $\pm 30 \mathrm{mg}$ samples of fish muscle tissue were taken and put into a 1.5 $\mathrm{ml}$ microcentrifuge tube, subsequently $200 \mathrm{ml}$ GT Buffer was added and homogenized by grinding. Furthermore, 20 $\mathrm{ml}$ of Proteinase $\mathrm{K}$ was added and incubated at $60{ }^{\circ} \mathrm{C}$ for 30 minutes, with inverting the tube every 5 minutes during incubation. $200 \mathrm{ml} \mathrm{GBT}$ Buffer was added and vortexed for five seconds. The mixture was incubated at $60{ }^{\circ} \mathrm{C}$ for 20 minutes, with inverting the tube every 5 minutes. Also, 200 $\mathrm{ml}$ absolute ethanol was added and vortexed for 10 seconds, and then the sample was placed to the GS column in a $2 \mathrm{ml}$ collection tube and centrifuged at 14,000-16,000 $\mathrm{g}$ for two minutes. The collection tube was discarded and transferred the GS column to a new collection tube. $400 \mathrm{ml}$ W1 Buffer was added to the GS column and centrifuged at $14,000-16,000 \mathrm{~g}$ for thirty seconds. The supernatant was removed, and the $600 \mathrm{ml}$ Wash Buffer was added to the GS column and centrifuged at 14,000-16,000 $\mathrm{g}$ for thirty seconds. After that, the supernatant was discharged, and the GS column was placed back in the collection tube and centrifuged at 14,000-16,000 $\mathrm{g}$ for three minutes. In the final step, the dried GS column was placed to a clean microcentrifuge tube, and the pre-heated Elution Buffer was added and centrifuged at 14,000-16,000 $\mathrm{g}$ for thirty seconds.
The mitochondrial Cytochrome Oxidase subunit I (COI) gene was chosen because the resolution of the COI gene at the intraspecific level is better than other core genes, so it was appropriate to be used to identify the species up to the intraspecific level (Strüder-Kypke and Lynn 2010). The mitochondrial DNA COI gene was further amplified using a forward primer pair FF2d 5'-TTC TCC ACC AAC CAC AAR GAY ATY GG-3' and reverse primer FR1d 5'-CAC CTC AGG GTG TCC GAA RAA YCA RAA-3' (Ivanova et al. 2007). One sample, i.e. N16, was amplified using the LCOI490 forward primer pair (5'GGT CAA CAA ATA ATA AAG ATA TTG G-3') and reverse primer HC02198 5'-TAA ACT TCA GGG TGA CCA AAA AAT CA-3' (Folmer et al. 1994) because it was unsuccessfully amplified using FF2d and FR1d primers. The PCR profiles were predenaturation at $94^{\circ} \mathrm{C}$ for five minutes, denaturation at $94^{\circ} \mathrm{C}$ for 30 seconds, primary attachment at $50^{\circ} \mathrm{C}$ for 30 seconds, elongation at $72^{\circ} \mathrm{C}$ for 45 seconds, and final elongation at $72^{\circ} \mathrm{C}$ for seven minutes. The PCR process lasted for 40 cycles and the DNA samples that had been amplified and electrophoresed were then sequenced. The sequencing process was performed at Malaysia's $1^{\text {st }}$ Base Laboratory through PT Genetika Science Indonesia by sending samples consisting of PCR Product of $30 \mu \mathrm{L}$ DNA samples, $10 \mu \mathrm{L}$ forward primers, and $10 \mu \mathrm{L}$ reverse primers.

\section{Data analysis}

The standardized morphometric characters were analyzed using Discriminant Function Analysis (DFA) (Landau and Everit 2004) using IBM SPSS Statistics 20. The molecular data sequencing process was carried out using Dideoxy Sanger Termination Method through PT Genetika Science Indonesia. Nucleotide sequences from DNA sequencing that had been processed and carried out by CONTIG were then matched with data available on the National Center for Biotechnology Information (NCBI) databases through the BLAST (Basic Local Alignment Search Tool). Phylogenetic trees are arranged by aligning the DNA sequences of the identified samples with some goby DNA samples available in the GenBank database. The phylogenetic tree was created using Maximum Likelihood 1000 bootstrap method in MEGA 6.0 software.

\section{RESULTS AND DISCUSSION}

\section{Species identification}

Nike is a group of small fish at the post-larval and juvenile stages which generally have a transparent body at the beginning until they turn blackish at the end of the appearance period when the fish have entered the river estuary (Pasisingi et al. 2020a). Based on a cursory observation, Nike fish is a composition of small fish grouped with the same morphological appearance. However, if this is observed in detail, the fish show a variety of melanophore patterns on their bodies. From a total of 2,523 Nike fish samples caught during the study period, 1,856 fish samples were found with different melanophore patterns than previously reported by Sahami et al. (2019b). This study found 15 new melanophore patterns (sample code N6-N20) presented in Figure 3. 

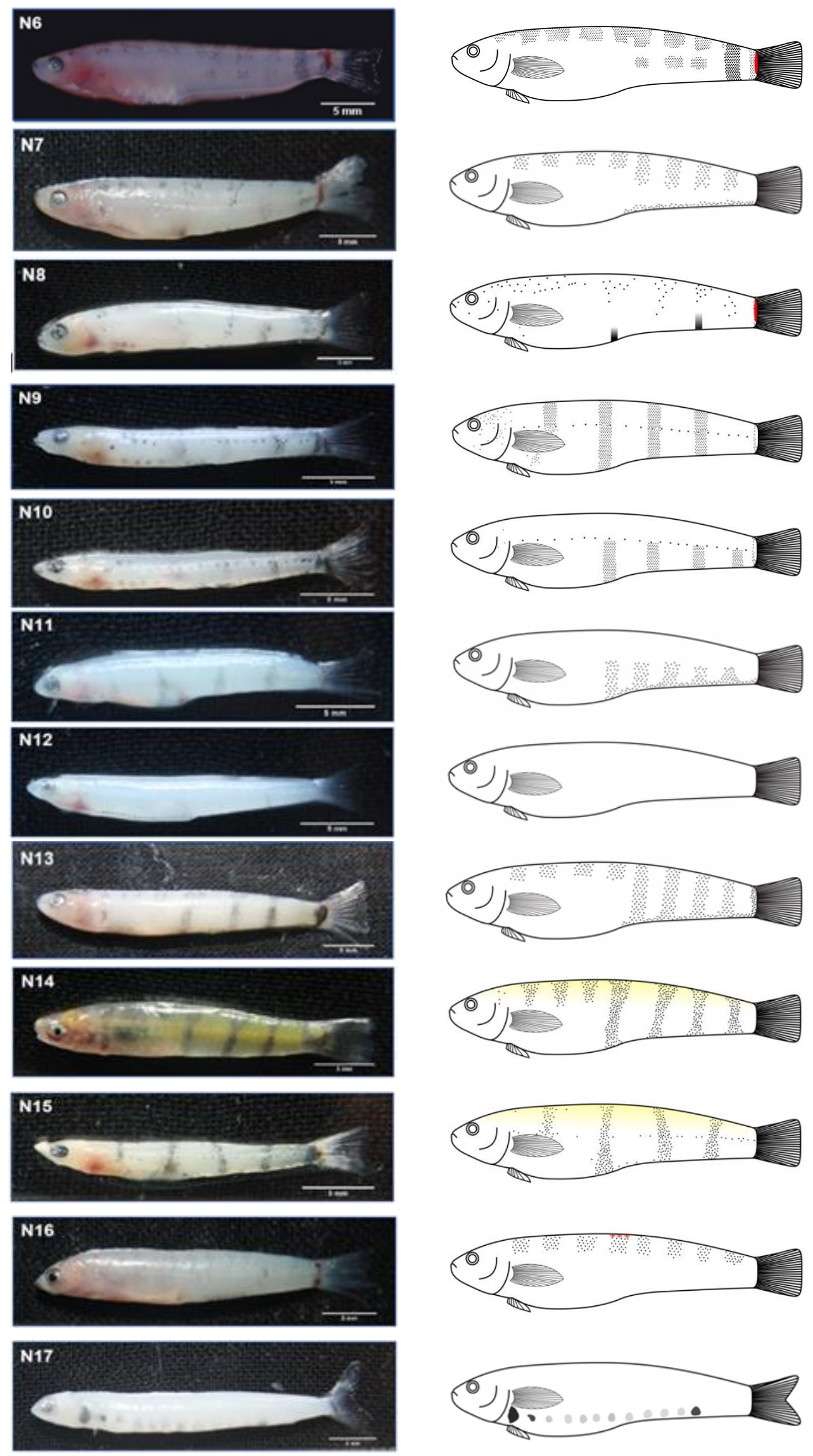

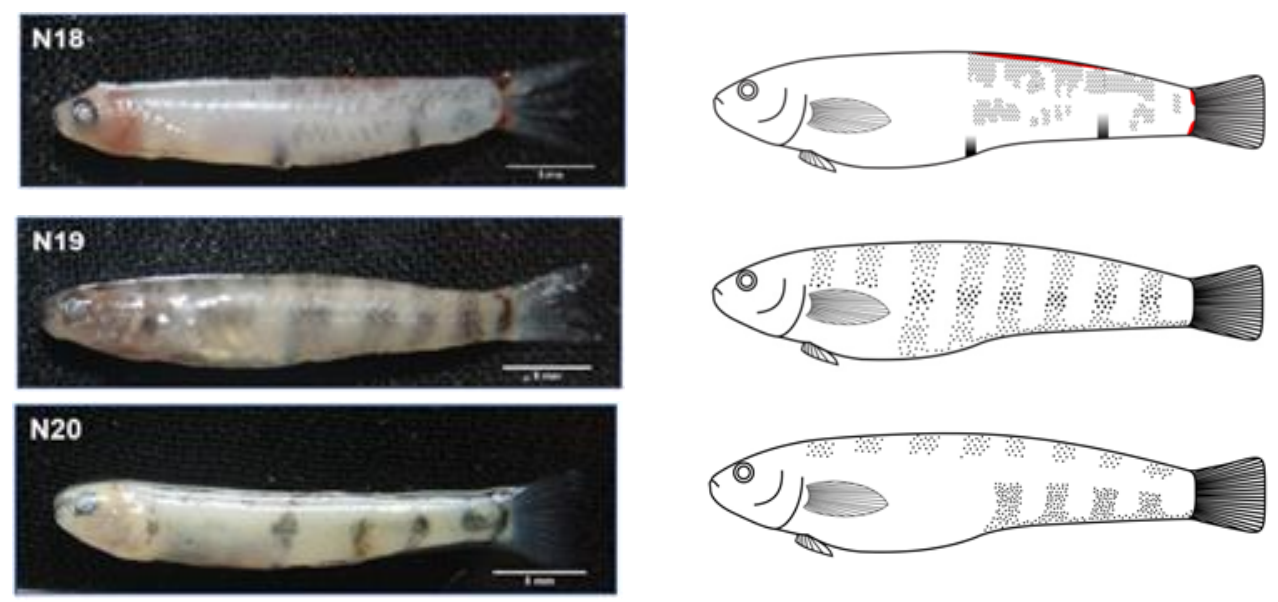

Figure 3. A new record on the melanophore pattern diversity of species composers of Nike fish in Gorontalo Bay Waters (notes: the sketch of melanophore pattern does not use actual fish size)

Generally, the caught Nike fish have a total length of 16.22-37.69 $\mathrm{mm}$, do not have scales, the fins are not perfect, and the caudal fins tend to form truncates. One sample, i.e. N17, is the only sample whose caudal fins form a clear fork. Each group of melanophore patterns was caught in a range of different sizes as presented in Table 2. This table shows that the Nike fish assemblages do not only consist of fish with different melanophore patterns, but also different sizes. In a single Nike catch, the size of each group of melanophore patterns is very diverse and shows a certain tendency to group. The highest caught samples in the observation period were 508 for $\mathrm{N} 1$, while the lowest caught samples were N4 and N17 (i.e. one sample for each).

\section{Morphometric data analysis}

Morphometric characters can be used in taxonomies as initial identification in fisheries (Sara et al. 2016). A summary of the results of morphometric character data measurements that have been standardized follows the allometric formula Elliott et al. (1995) as presented in Table 3.

Discriminant analysis is an analysis used to define morphometric characters distinguishing among populations (Landau and Everit 2004). The distribution of the discriminant coefficient values presented in the form of canonical discriminant function diagrams shows the 20 types of species that compose the Nike fish assemblages with different melanophore patterns in Gorontalo Bay forming three clusters as presented in Figure 4.

Each of the two discriminant functions can describe $63.9 \%$ and $19 \%$ of the total morphometric variant characters. Based on the analysis of discriminant functions, the C6 (head length) character was the highest character, which suggested that the main distinguishing character among Nike populations in the Gorontalo Bay waters could be determined from the head length character. Figure 4 obviously shows that Nike fish samples in the Gorontalo Bay waters formed three clusters, N1, N2, N4, N6, N7, N8, N13, N14, N16, N18, N19, and N20) in the first cluster;
$\mathrm{N} 3, \mathrm{~N} 4, \mathrm{~N} 5, \mathrm{~N} 9, \mathrm{~N} 10$, and N15 in the second cluster; and $\mathrm{N} 11$ and N12 in the third cluster. One sample, i.e. N17, does not show a tendency to be included in certain clusters. Besides, the forked caudal fin shows that N17 is not a member of the goby group and is strongly suspected of being accidentally caught.

Sahami et al. (2019b) reported species N1 as $S$. pugnans; N2 as S. cynocephalus; N3 and N5 as B. segura; and $\mathrm{N} 4$ as $B$. gyrinoides. The diagram of canonical discriminant function classifies $\mathrm{N} 1$ and $\mathrm{N} 2$ in the first cluster, so it is strongly alleged that other species in the first cluster (N4, N6, N7, N8, N13, N14, N16, N18, N19, and N20) are species in the Sicyopterus genus or at least is a species in the Gobiidae family. Also, N3, N4, and N5 as species in Eleotridae family are present in the second cluster, so it is also strongly alleged that other species in the second cluster (N9, N10, and N15) are the members of Eleotridae family. On the other hand, N11 and N12 as separate clusters have not yet ascertained for the tendency of their species identity. However, the morphological character with the fused pelvic fins implies that both species are the members of Gobiidae family and not generated from the Sicyopterus genus. Nurjirana et al. (2019b) stated that the fundamental difference from the morphology of Gobiidae and Eleotridae fish lies in the shape of the pelvic fins, where the Gobiidae fish has fused pelvic fins, forming a ventral disc and Eleotridae has separated pelvic fins

\section{Molecular analysis}

The molecular analysis succeeded in identifying 14 of the 15 new melanophore pattern samples, while one sample, N17, was not identified since the sample was damaged and there were no more sample reserves. The results of mitochondrial COI gene sequencing indicate that the Nike fish assemblages in Gorontalo Bay consist of six different species. The results of BLAST of DNA mitochondrial COI gene sequence data on www.blast.ncbi.nlm.nih.gov are presented in Table 4. 
Table 2. Range of catch size of each species composers of Nike fish assemblages in Gorontalo Bay, Indonesia
Table 4. The Results of Nike Fish BLAST in Gorontalo Bay on NCBI website

\begin{tabular}{cccc}
\hline $\begin{array}{c}\text { Sample } \\
\text { code }\end{array}$ & $\begin{array}{c}\text { Mean of total } \\
\text { length }(\mathbf{c m})\end{array}$ & $\begin{array}{c}\text { Range of total } \\
\text { length }(\mathbf{c m})\end{array}$ & $\begin{array}{c}\text { Number of } \\
\text { samples }\end{array}$ \\
\hline N1 & 2.765 & $1.964-3.547$ & 508 \\
N2 & 2.764 & $2.383-3.326$ & 81 \\
N3 & 2.153 & $1.917-2.372$ & 54 \\
N4 & 2.089 & 2.089 & 1 \\
N5 & 2.063 & $1.892-1.943$ & 23 \\
N6 & 3.043 & $2.345-3.658$ & 190 \\
N7 & 2.777 & $2.415-3.748$ & 399 \\
N8 & 2.796 & $2.379-3.333$ & 277 \\
N9 & 2.204 & $1.897-2.362$ & 27 \\
N10 & 2.314 & $2.283-2.344$ & 2 \\
N11 & 1.931 & $1.622-2.103$ & 140 \\
N12 & 2.019 & $1.694-2.369$ & 191 \\
N13 & 2.767 & $2.480-3.347$ & 240 \\
N14 & 2.642 & $2.386-2.863$ & 50 \\
N15 & 2.181 & $2.002-2.357$ & 42 \\
N16 & 3.042 & $2.579-3.769$ & 129 \\
N17 & 3.768 & 3.768 & 1 \\
N18 & 2.952 & $2.840-3.118$ & 4 \\
N19 & 3.208 & $2.900-3.507$ & 31 \\
N20 & 2.774 & $2.452-3.628$ & 133 \\
Total sample & & & 2,523 \\
\hline
\end{tabular}

Some samples with different melanophores had the same genetic profile so that they were identified as the same species. Table 3 shows that the Nike fish assemblages in Gorontalo Bay are composed of six species from two different families (i.e. S. parvei Bleeker 1853, $S$. cynocephalus, S. longifilis, S. lagocephalus, and Stiphodon semoni) from the Gobiidae family; and Belobranchus belobranchus Valenciennes 1837 from the Eleotridae family. One species, S. longifilis, is the same species as reported by Olii et al. (2019) without a description of specific melanophore patterns, and one species, $S$. cynocephalus, is also the same species with a different melanophore pattern as reported by Sahami et al. (2019b).

\begin{tabular}{ll}
\hline Sample code & Species \\
\hline N6 & Sicyopterus parvei \\
N7 & Sicyopterus longifilis \\
N8 & Sicyopterus cynocephalus \\
N9 & Belobranchus belobranchus \\
N10 & Belobranchus belobranchus \\
N11 & Stiphodon semoni \\
N12 & Stiphodon semoni \\
N13 & Sicyopterus longifilis \\
N14 & Sicyopterus longifilis \\
N15 & Belobranchus belobranchus \\
N16 & Sicyopterus cynocephalus \\
N18 & Sicyopterus lagocephalus \\
N19 & Sicyopterus parvei \\
N20 & Sicyopterus longifilis \\
\hline
\end{tabular}

The results of molecular analysis were able to identify the samples up to the species level and further clarify the results of morphometric analysis. The first cluster was a group of species in the genus Sicyopterus; the second cluster was a group of species in the Eleotridae family, and the third cluster was a group of species in the genus Stiphodon. Alleged N11 and N12 samples as the members of species in the Gobiidae family and not the members of species in the genus Sicyopterus were also confirmed through molecular analysis that succeeded in identifying the two species as Stiphodon semoni species. Overall, it can be emphasized that Nike fish has a fairly high level of diversity, both in terms of its constituent species and melanophore patterns at the species level. The overall kinship relationships of the species of Nike fish assemblages in the Gorontalo Bay waters based on the nucleotide sequence of the mitochondrial DNA COI gene are presented in Figure 5.

Table 3. Morphometric characters data of each species composers of Nike fish assemblages in Gorontalo Bay, Indonesia

\begin{tabular}{|c|c|c|c|c|c|c|c|c|c|}
\hline \multirow{2}{*}{$\begin{array}{c}\text { Sample } \\
\text { code }\end{array}$} & \multicolumn{9}{|c|}{ Unit of Character $(\mathrm{cm})$} \\
\hline & SL & PL & ED & EP & HL & BD & PD & EA & YS \\
\hline N1 & $2.237 \pm 0.10$ & $112 \pm 0.02$ & $131 \pm 0.01$ & $116 \pm 0.13$ & $447 \pm 0.04$ & $.403 \pm 0.09$ & $0.188 \pm 0.08$ & $.018 \pm 0.01$ & $063 \pm 0.02$ \\
\hline $\mathrm{N} 2$ & $2.214 \pm 0.05$ & $7 \pm 0.02$ & $2 \pm 0.02$ & & & \pm 0.04 & $28 \pm 0.03$ & $14 \pm 0.00$ & $60 \pm($ \\
\hline N3 & 7 & \pm 0.01 & 1 & 2 & & 02 & 01 & & $38 \pm$ \\
\hline N4 & $3 \pm \mathrm{a}$ & $3 \pm \mathrm{a}$ & $166 \pm a$ & $6 \pm a$ & $\mathrm{a}$ & $2 \pm a$ & $\pm \mathrm{a}$ & & $0.201=$ \\
\hline N5 & $.258 \pm 0.08$ & $58 \pm 0.02$ & $0.150 \pm 0.01$ & $.095 \pm 0.02$ & $7 \pm 0.04$ & $79 \pm 0.02$ & $56 \pm 0.02$ & $22 \pm 0.00$ & $0.065 \pm 0.03$ \\
\hline $\mathrm{N}$ & $=0.04$ & $=0.02$ & 1 & \pm 0.17 & & $6 \pm 0.10$ & $97 \pm 0.11$ & & $1 \pm 0.04$ \\
\hline N7 & $243 \pm 0.04$ & \pm 0.02 & 0.1 & & & & & & 0.02 \\
\hline $\mathrm{N}$ & $238 \pm 0.01$ & $=0.02$ & & & & & & & .03 \\
\hline $\mathrm{N}$ & & & & & & & & & .02 \\
\hline & & & & & & & & & 0.01 \\
\hline & & & & & & & & & \\
\hline & 56 & & & & & & & & \pm 0.04 \\
\hline & $45 \pm 0.04$ & \pm 0.02 & \pm 0.01 & 16 & & 0.11 & 20 & 02 & $9 \pm 0.02$ \\
\hline & $40 \pm 0.03$ & \pm 0.01 & \pm 0.01 & & & 03 & 02 & 00 & $7 \pm 0.01$ \\
\hline & 4 & & & & & & & & \pm 0.02 \\
\hline N16 & $2.216 \pm 0.04$ & $0.111 \pm 0.02$ & $0.133 \pm 0.01$ & $0.045 \pm 001$ & 0.43 & 0.03 & 0.258 & $0.012 \pm 0.00$ & $0.051 \pm 0.01$ \\
\hline N17 & $2.352 \pm \mathrm{a}$ & $\mathbf{1}$ & $2-a$ & & & $2 \pm \mathrm{a}$ & $-a$ & & $0.047 \pm \mathrm{a}$ \\
\hline N18 & $2.229 \pm 002$ & $10 \pm 0.02$ & \pm 0.00 & $49 \pm 0.00$ & & $.369 \pm 0.02$ & $252 \pm 0.02$ & $.010 \pm 0.00$ & $.037 \pm 0.01$ \\
\hline & $2.225 \pm 0.03$ & $0.113 \pm 0.01$ & $24 \pm 0.00$ & $0.038 \pm 0.00$ & & $50 \pm 0.03$ & $79 \pm 0.02$ & $0.009 \pm 0.00$ & $0.057 \pm 0.02$ \\
\hline $\mathrm{N} 20$ & $2.243 \pm 0.05$ & $0.109 \pm 0.01$ & $0.131 \pm 0.01$ & $0.172 \pm 0.17$ & $0.462 \pm 0.05$ & $0.369 \pm 0.10$ & $0.152 \pm 0.10$ & $0.029 \pm 0.03$ & $0.065 \pm 0.02$ \\
\hline
\end{tabular}




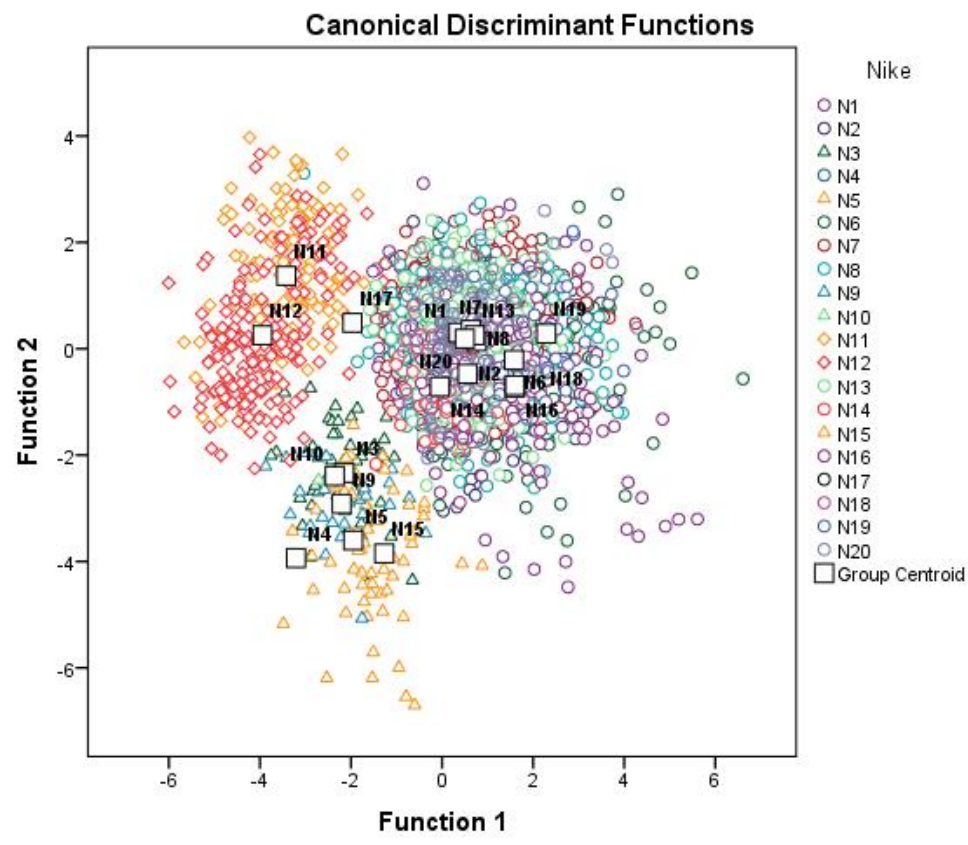

Figure 4. Canonical discriminant function of nike fish in Gorontalo Bay Waters, Indonesia

The phylogenetic tree (Figure 5) shows that the species composing the Nike fish in the Gorontalo Bay waters form two monophyletic clades as family clades. The first monophyletic clade is the Gobiidae family clade which includes two genera and six species. The first genus is Sicyopterus which includes five species (i.e. $S$. cynocephalus, S. parvei, S. lagocephalus, S. longifilis, and S. Pugnans). The second genus is Stiphodon which consists of only one species (i.e. Stiphodon semoni). The second monophyletic clade is the Eleotridae family which includes two genera and three species (i.e. Bunaka gyrinoides, Belobranchus segura, and B. belobranchus).

\section{Discussion}

Fish school migration strategy is a consequence of the amphidromous species in avoiding predators and foraging food when migrating from marine waters at the post-larval stage to the river (Keith 2003). According to Thacker and Roje (2011), the diversity of Gobies at the post-larval and juvenile stages is often unnoticed because of their small size and unclear ecology. The use of melanophore patterns in morphological grouping is inspired by the research conducted by Yamasaki et al. (2011) which stated that the larvae of newly hatched goby can be distinguished based on their melanophore pattern.

This study found 15 new melanophore patterns (Figure 3) that can distinguish and classify the fish composing Nike fish assemblages from one another. The combination of their morphological characters and diagram of canonical discriminant function (Figure 4) shows that morphometric characters can be used in determining samples up to family level, but it cannot identify the samples up to the genus or even species level. These results are in line with research conducted by Watanabe et al. (2011) which also had not been able to identify the $S$. japonicus post-larvae based on its morphological characters since the morphology is still very common as the morphological characters of other Gobioidei fish larvae. Thacker and Roje (2011) stated that Gobiidae fish have few morphological characters that can be used to group subgroups in the family even though the diversity of its species is quite high. Roesma et al. (2020) said that Gobies develop various morphological specialties as an adaptation to their environment, making it difficult to estimate the evolutionary scenarios by using morphological information only.

Subsequently, molecular identification was performed to confirm the identity of species that cannot be demonstrated either by the morphological features of the species or their morphometric characters. Mitochondrial DNA markers (mtDNA) had been widely used for most systematic molecular studies compared to nuclear DNA due to the large number of copies obtained from one cell, their small size, haploid in nature, and evolving faster (Teletchea 2009). The COI gene is the fastest and most reliable gene used as a barcoding marker to identify species (Hubert et al. 2008; Bingpeng et al. 2018; Roesma et al. 2018; Roesma et al. 2019). Initially, the COI gene has also been widely used to identify the species in Gobioidei assemblages (Jeon et al. 2012; Thomas et al. 2013; Viswambharan et al. 2013; Jin et al. 2014; Taillebois et al. 2014; Lejeune et al. 2016; Wang et al. 2017; Linh et al. 2018; Olii et al. 2019; Roesma et al. 2020). Therefore, this study also used the COI gene to identify species. 


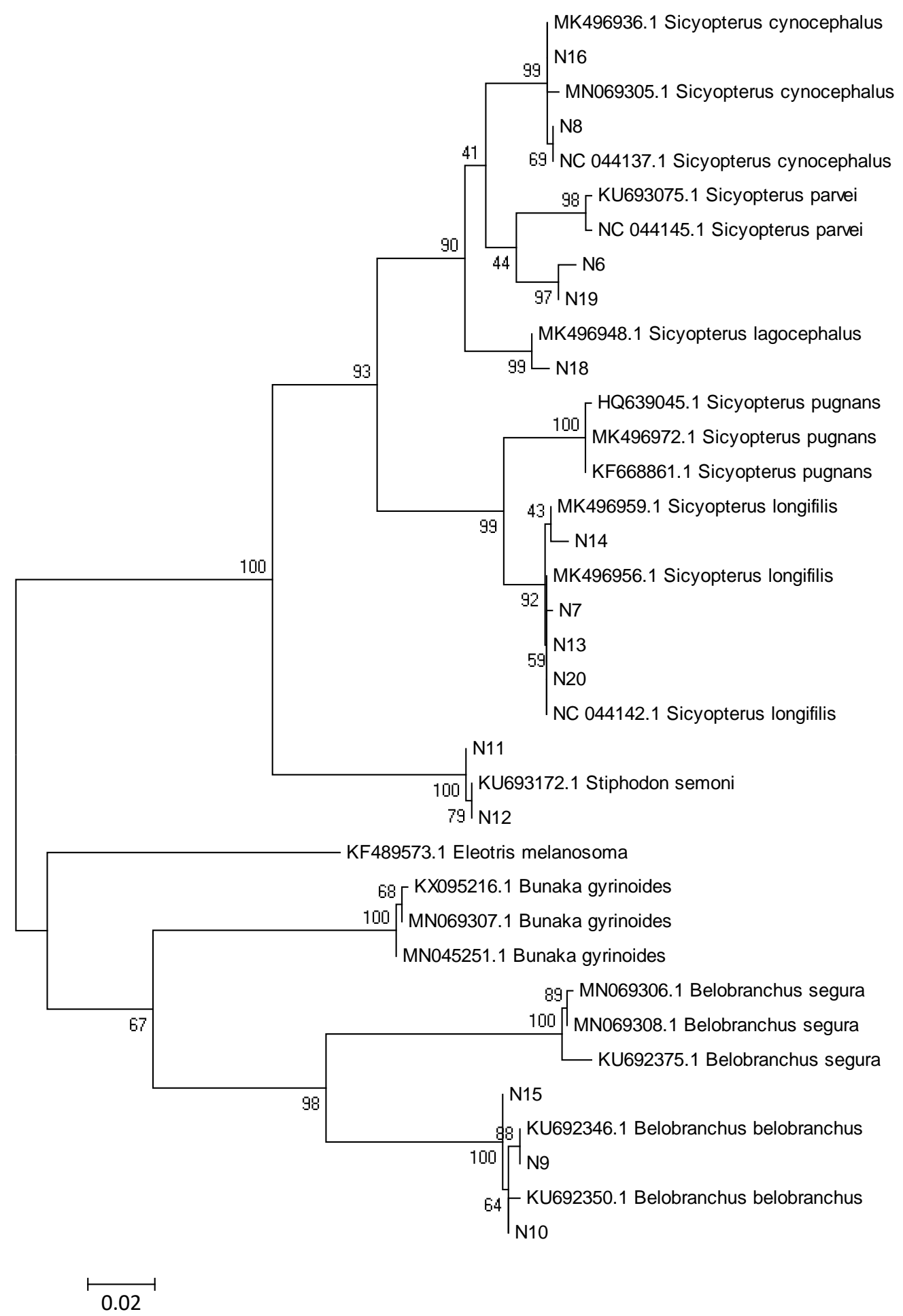

Figure 5. Phylogenetic tree of Nike fish composers in the Gorontalo Bay Waters, Indonesia

Several samples with different melanophore patterns were found having the same genetic identity. This was affected by some factors, such as environment, age, and natural dichromatism that might appear when the adult stage. Ellien et al. (2014); Valade et al. (2009) explained that $S$. lagocephalus larvae changes in the appearance of chromatophores in its body that starts from the head area and spreads along the body as the larvae get older. The identical results were obtained by Sahami et al. (2019a), which found an increase in the number of melanophores in the body of the Nike Belobranchus segura fish when entering the estuary areas. Keith (2003) noted that freshwater Gobioidei fish are not hermaphrodite and do not have sexual change or alternative sexual strategies, but usually occur in sexual dichromatism in adult stage, where males have a brighter color than females. Larmuseau et al. (2010), in his research, revealed that natural selection might also affect the genetic variation in cone opsins in 
species that could have an impact on the evolution of polymorphism.

The results of molecular identification indicate that the new melanophore patterns of Nike fish in Gorontalo Bay waters were composed of six species (i.e. S. parvei, $S$. cynocephalus, S. longifilis, S. lagocephalus, $B$. Belobranchus, and Stiphodon semoni). Nike fish was initially reported as a single species A. Melanocephalus by Usman (2016) and Sicyopterus longifilis by Olii et al. (2019). Recently, Sahami et al. (2019b) found the diversity of the composers species of Nike fish is S. pugnans, $S$. cynocephalus, Bunaka gyrinoides, and Belobranchus segura. This study successfully found and identified four new composers species of Nike fish, such as $S$. parvei and S. lagocephalus, and Stiphodon semoni generated from the Gobiidae family, and B. Belobranchus generated from the Eleotridae family.

$94.09 \%$ (2,374 samples) out of a total of 2,523 samples whose morphometric characters were observed are species in the Gobiidae family. In addition to the high quantity of the catches, the species in the Gobiidae family also show its highest diversity of melanophore and genetic patterns compared to the Eleotridae family. According to Thacker and Roje (2011), Gobiidae is one of the largest Acanthomorph fish assemblages consisting of $\pm 1,120$ species from 30 genera that have been described. Sicydiinae subfamily (Teleostei: Gobioidei) is the largest subfamily that contributes to the diversity of fish communities in tropical river waters with nine genera and more than 110 species that have been described. Nine genera of the Sicydiinae subfamily are Sicydium Valenciennes 1837; Sicyopterus Gill 1860; Lentipes Günther 1861; Sicyopus Gill 1863; Cotylopus Guichenot 1864; Stiphodon Weber 1895; Parasicydium Risch 1980; Smilosicyopus Watson 1999; and Akihito Watson, Keith and Marquet 2007 (Keith et al. 2011; Taillebois et al. 2014). The genus Sicyopterus of the Sicydiinae subfamily is the genus with the highest diversity of species and is widely distributed to the Indo-Pacific tropical islands (Keith et al. 2005; Keith et al. 2015; Lord et al. 2019). It strengthens the results of this study which found Sicyopterus as the genus with the highest diversity of Gorontalo Bay waters.

The $S$. parvei species are known to be Indonesian local endemic (LE) (Lord et al. 2019). Its distribution in Indonesia was found in Manggarai, Flores (Tjakrawidjaja 2002); Sukamade river, East Java (Rukmana et al. 2014); and Java and Bali (Dahruddin et al. 2016). Meanwhile, $S$. lagocephalus species is known as the species of genus Sicyopterus with the most extensive distribution in the Indo-Pacific region (Keith et al. 2005; Lord et al. 2019). This species was also found in La Réunion island (Keith et al. 2008); Vanuatu, Futuna and Okinawa (Keith et al. 2011); Buleleng, Bali (Dahruddin et al. 2016); Leppangan river, East Sulawesi (Nurjirana et al. 2019a); and Luwuk Banggai, Central Sulawesi (Gani et al. 2019).

The adult species of $B$. belobranchus was found in Bone river, Gorontalo (Pasisingi et al. 2020b), and further strengthen the discovery at the post-larval and juvenile stages in this study. Besides, the distribution of this species in Indonesia had been reported in Manggarai, Flores (Tjakrawidjaja 2002); Sukamade, East Java (Rukmana et al. 2014); and Luwuk Banggai, Central Sulawesi (Gani et al. 2019). The discovery of B. belobranchus species in the Gorontalo Bay waters contributes to the diversity of species in the genus Belobranchus which was previously only found for one species, i.e. B. segura.

The Stiphodon semoni species, the Opal cling goby, is one of the economically important species in the world of ornamental fish trade (Maeda and Tan 2013; Hubert et al. 2015). The distribution of this species in Indonesia was found in Lampung (Watson 2008), Bengkulu (Maeda and Tan 2013), Sukabumi, West Java (Dahruddin et al. 2016); Leppangan River, West Sulawesi (Nurjirana et al. 2019a); and Luwuk Banggai, Central Sulawesi (Gani et al. 2019).

The A. melanocephalus species, which was initially reported by Usman (2016) as a Nike species in Gorontalo Bay, was not found in this study because the sampling time did not coincide with the spawning time of the species. As explained in Yamasaki et al. (2011), it showed that the spawning season for A. melanocephalus was June to November, while the sampling was done in January-March. Besides, species extinction might occur due to overfishing and habitat change. However, in-depth research needs to be conducted to fulfill scientific information on Gorontalo aquatic biodiversity.

Having described above, it has been genetically confirmed for 10 species of Gobies as a constituent of the Nike fish assemblages in the Gorontalo Bay waters to date and it is possible to find more other species in line with further advancements in science and research. This study has been successfully grouping and identifying the species based on their morphometric and molecular characters, as well as being the initial identity of the melanophore pattern characters of each Nike fish compiler. These data are also very worthwhile as the reference for the inventory of Nike fish species in other places on the coast of Tomini Bay and other areas. Salam et al. (2016) stated that Nike fish assemblages in Gorontalo could be found in several milango (estuary areas). Besides being found in the estuary of the Bone Bolango River in Gorontalo, which is the location of this study, Nike fish assemblages also often appear in several estuary areas (i.e. Taludaa, Paguyaman, and Marisa). Nike fish caught at these locations are also consumed by the local community or sold in urban areas, making it one of the important fisheries commodities in Gorontalo. However, scientific information concerning Nike fish in these locations does not yet exist and should be sought as soon as possible. The results of this study can also be information for exploring adult gobies in the river and finding out their distribution in nature.

\section{ACKNOWLEDGEMENTS}

The authors would like to express their gratitude to the Rector of Gorontalo State University for granting permission and supporting the accomplishment of this research. Also, the greatest gratitude goes to Mohamad Rusdiyanto Puluhulawa for the research fund. The authors 
also thank Thomas Tammu and Zulkifli Karim for their technical assistance and all those who have contributed to this study. Finally, the authors thank the anonymous reviewers for their constructive input and contribution in improving the quality of this manuscript.

\section{REFERENCES}

Benbow ME, Burky AJ, Way CM. 2004. Morphological characteristics and species separation of Hawaiian postlarval amphidromous fishes. Micronesica 37 (1): 129-144.

Bingpeng X, Heshan L, Zhilan Z, Chunguang W, Yanguo W, Jianjun W. 2018. DNA barcoding for identification of fish species in the Taiwan Strait. PLoS One 13 (6): e0198109. DOI 10.1371/journal.pone.0198109.

Dahruddin H, Hutama A, Busson F, Sauri S, Hanner R, Keith P, Hadiaty R, Hubert N. 2016. Revisiting the ichthyodiversity of Java and Bali through DNA barcodes: taxonomic coverage, identification accuracy, cryptic diversity and identification of exotic species. Mol Ecol Resour 17 (2): 1-12.

Ellien C, Werner U, Keith P. 2014. Morphological changes during the transition from freshwater to seawater in an amphidromous goby, Sicyopterus lagocephalus (Pallas 1770) (Teleostei). Ecol Freshw Fish 25 (1): 1-12. DOI: 10.1111/eff.12190.

Elliott NG, Haskard K, Koslow JA. 1995. Morphometric analysis of orange roughy (Hoplostethus atalanticus) off the continental slope of southern Australia. J Fish Biol 46 (2): 202-220.

Firawati I, Murwantoko, Setyobudi E. 2017. Morphological and molecular characterization of hairtail (Trichiurus spp.) from the Indian Ocean, southern coast of East Java, Indonesia. Biodiversitas 18 (1): 190-196.

Folmer O, Black M, Hoeh W, Lutz R, Vrijenhoek R. 1994. DNA primers for amplification of mitochondrial Cytochrome $\mathrm{C}$ Oxidase subunit I from diverse metazoan invertebrates. Mol Mar Biol and Biotechnol 3 (5): 294-299.

Gani A, Bakri AA, Adriany DT, Nurjirana N, Herjayanto M, Bungalim MI, Ndobe S, Burhanuddin AI. 2019. Identification of freshwater goby species from The Biak and Koyoan Rivers, Luwuk Banggai, Central Sulawesi. J Ilmu Kel Spermonde 5 (2): 57-60.

Habibie SA, Djumanto, Murwantoko. 2018. Polikromatik, dimorfisme seksual, dan redeskripsi spesies ikan red devil Amphilophus amarillo [Stauffer \& McKaye, 2002] di Waduk Sermo Yogyakarta. J Iktiologi Indones 18 (1): 69-86. [Indonesian]

Hubert N, Hanner R, Holm E, Mandrak NE, Taylor E, Burridge M, Watkinson D, Dumont P, Curry A, Bentzen P, Zhang J, April J, Bernatchez L. 2008. Identifying Canadian freshwater fishes through DNA barcodes. PLoS One 3(6): e2490. DOI: 10.1371/journal.pone.0002490.

Hubert N, Kadarusman, Wibowo A, Busson F, Caruso D, Sulandari S, Nafiqoh N, Poiyaud L, Ruber L, Avarre JC, Herder F, Hanner R, Keith P, Hadiaty RK. 2015. DNA Barcoding Indonesian freshwater fishes: challenges and prospects. DNA Barcodes 3: 144-169.

Ivanova NV, Zemlak TS, Hanner RH, Hebert PDN. 2007. Universal primer cocktails for fish DNA barcoding. Mol Ecol Notes 7(4): 544548.

Jeon HB, Choi SH, Suk HY. 2012. Exploring the utility of partial cytochrome c oxidase subunit 1 for DNA barcoding of gobies. Anim Syst Evol Divers 28 (4): 269-278.

Jin X, Wang R, Wei T, Tang D, Xu T. 2014. Complete mitochondrial genome sequence of Tridentiger bifasciatus and Tridentiger barbatus (Perciformes, Gobiidae): a mitogenomic perspective on the phylogenetic relationships of Gobiidae. Mol Biol Rep 42: 253-265.

Keith P. 2003. Biology and ecology of amphidromous Gobiidae of the Indo-Pacific and the Caribbean regions. J Fish Biol 63: 831-847.

Keith P, Galewski T, Cattaneo-Berrebi G, Hoareau T, Berrebi P. 2005. Ubiquity of Sicyopterus lagocephalus (Teleostei: Gobioidei) and phylogeography of the genus Sicyopterus in the Indo-Pacific area inferred from mitochondrial cytochrome b gene. Mol Phylogenet Evol 37: 721-732.

Keith P, Hoareau TB, Lord C, Ah-Yane O, Gimonneau G, Robinet T, Valade P. 2008. Characterisation of post-larval to juvenile stages, metamorphosis and recruitment of an amphidromous goby,
Sicyopterus lagocephalus (Pallas) (Teleosteil: Gobiidae: Sicydiinae). Mar Freshwater Res 59: 876-889.

Keith P, Lord C, Lorion J, Watanabe S, Tsukamoto K, Couloux A, Dettai A. 2011. Phylogeny and biogeography of Sicydiinae (Teleostei: Gobiidae) inferred from mitochondrial and nuclear genes. Mar Biol 158: 311-326

Keith P, Lord C, Busson F, Sauri S, Hubert N, Hadiaty RK. 2015. A new species of Sicyopterus (Gobiidae) from Indonesia. Cybium 39 (4): 243-248.

Landau S, Everit BS. 2004. A Handbook of Statistical Analyses using SPSS. Chapman \& Hall/CRC, Washington DC.

Larmuseau MHD, Vancampenhout K, Raeymaekers JAM, Houdt JKJ, Volckaert FAM. 2010. Differential modes of selection on the rhodopsin gene in coastal Baltic and North Sea populations of the sand goby, Pomatoschistus minutus. Mol Ecol 19 (11): 2256-2268.

Lejeune L, Tabouret H, Taillebois L, Monti D, Keith P. 2016. Larval traits of the Caribbean amphidromous goby Sicydium punctatum (Gobioidei: Sicydiinae) in Guadeloupe. Ecol Freshw Fish 25 (2): 272280.

Linh NM, Thu PT, Quan NV, Chien PV, Ly DH, Nhan DV, Len DT. 2018. DNA barcoding application of mitochondrial COI gene to identify some fish species of family Gobiidae in Vietnam. J Mar Sci Tech-Japan 18 (4): 433-451.

Lord C, Bellec L, Dettaï A, Bonillo C, Keith P. 2019. Does your lipstick? Evolutionary aspects of the mouth morphology of the Indo-Pacific clinging goby of the Sicyopterus genus (Teleostei: Gobioidei: Sicydiinae) based on mitogenome phylogeny. J Zoolog Syst Evol Res 2019;00: 1-16. DOI: 10.1111/jzs.12291.

Maeda K, Tan HH. 2013. Review of Stiphodon (Gobiidae: Sicydiinae) from Western Sumatra, with Description of a New Species. Raffles B Zool 61 (2): 749-761.

Mennesson MI, Maeda K, Keith P. 2019. Evolutionary aspects of cephalic sensory papillae of the Indo-Pacific species of Eleotris (Teleostei: Eleotridae). Zool Scr 48 (5): 627-639.

Nurjirana, Burhanuddin AI, Haris A. 2019a. Diversity of penja fish (amphidromous goby) in Leppangan River, West Sulawesi, Indonesia. AACL Bioflux 12 (1): 246-249.

Nurjirana, Haris A, Sahami FM, Keith P, Burhanuddin AI. 2019b. Preliminary note on the morphological characters of penja (amphidromous goby post larvae) in West Sulawesi and Gorontalo Bay. IOP Conference Series: Earth and Environ Sci 370 (1): 1-7.

Olii AH, Sahami FM, Hamzah SN, Pasisingi N. 2017. Preliminary findings on distribution pattern of larvae of nike fish (Awaous sp.) in the estuary of Bone River, Gorontalo Province, Indonesia. AACL Bioflux 10: 1110-1118.

Olii AH, Sahami FM, Hamzah SN, Pasisingi N. 2019. Molecular approach to identify gobioid fishes, "Nike" and "Hundala" (local name), from Gorontalo Waters, Indonesia. Online J Biol Sci 19 (1): 51-56.

Pangemanan NP, Kepel RC, Bataragoa NE, Tumbol R, Sahami FM. 2020. Morphological and molecular identification of nike fish, Ophioleotris aporos in Tondano Lake, North Sulawesi, Indonesia. AACL Bopflux 13 (3): 1614-1621.

Pasisingi N, Abdullah S. 2018. Pola kemunculan ikan nike (Gobiidae) di Perairan Teluk Gorontalo, Indonesia. Depik 7 (2): 111-118. [Indonesian]

Pasisingi N, Olii AH, Habibie SA. 2020a. Morphology and growth pattern of Nike fish (amphidromous goby larvae) in Gorontalo Waters, Indonesia. Tomini J Aquat Sci 1 (1): 1-7.

Pasisingi N, Habibie SA, Olii AH. 2020b. Are Awaous ocellaris and Belobranchus belobranchus the two species of Nike fish schools?. Aceh J Anim Sci 5 (2): 87-91.

Roesma DI, Tjong DH, Munir W, Aidil DR. 2018. New record species of Puntius (Pisces: Cyprinidae) from West Sumatra based on cytochrome oxidase 1 gene. Intl J Adv Sci Eng Inf Technol 8: 250256.

Roesma DI, Tjong DH, Karlina W, Aidil DR. 2019. Taxonomy confirmation of Puntius cf. binotatus from Gunung Tujuh Lake, Jambi, Indonesia based on cytochrome oxidase-I (COI) gene. Biodiversitas 20 (1): 54-60.

Roesma DI, Tjong DH, Aidil DR. 2020. Phylogenetic analysis of transparent gobies in three Sumatran lakes, inferred from mitochondrial cytochrome oxidase I (COI) gene. Biodiversitas 21 (1): 43-48.

Rukmana RM, Trijoko, Pratiwi R. 2014. Keragaman ikan anggota ordo perciformes di Sungai Sukamade Taman Nasional Meru Betiri. Biomedika 7 (2): 46--52. [Indonesian] 
Sahami FM, Kepel RC, Olii AH, Pratasik SB. 2019a. Determination of morphological alteration based on molecular analysis and melanophore pattern of the migrating Nike fish in Gorontalo Bay, Indonesia. AACL Bioflux 12 (4): 1358-1365.

Sahami FM, Kepel RC, Olii AH, Pratasik SB. 2019b. What species make up the Nike fish assemblages at the macrotidal estuary in Gorontalo Bay, Indonesia? [version 1; peer review: 2 approved with reservation]. F1000Research 8: 1654. DOI: 10.12688/f1000research.19501.1.

Salam A, Sahami FM, Panigoro C. 2016. Nike (Awaous melanocephalus) fishery and mercury contamination in the estuary of Bone-Bolango River. Omni-Akuatika 12 (2): 130-136.

Sara L, Muskita WH, Astuti O, Safilu. 2016. The reproductive biology of blue swimming crab Portunus pelagicus in Southeast Sulawesi Waters, Indonesia. AACL Bioflux 9 (5): 1101-1112.

Strüder-Kypke M, Lynn DH. 2010. Comparative analysis of the mitochondrial cytochrome c oxidase subunit I (COI) gene in ciliates (Alveolata, Ciliophora) and evaluation of its suitability as a biodiversity marker. System Biodivers 8 (1): 131-148.

Taillebois L, Maeda K, Vigne S, Keith P. 2012. Pelagic larval duration of three amphidromous Sicydiinae gobies (Teleostei: Gobioidei) including widespread and endemic species. Ecol Freshw Fish 21 (4): 1-8. DOI: 10.1111/j.1600-0633.2012.00575.x.

Taillebois L, Castelin M, Lord C, Chabarria R, Dettaï A, Keith P. 2014. New sicydiinae phylogeny (Teleostei: Gobioidei) inferred from mitochondrial and nuclear genes: insights on systematics and ancestral areas. Mol Phylogenet and Evol 70: 260-271.

Teletchea F. 2009. Molecular identification methods of fish species: reassessment and possible applications. Rev Fish Biol Fish 19: 265293.

Thacker CE, Roje DM. 2011. Phylogeny of Gobiidae and identification of gobiid lineages. System Biodivers 9 (4): 329-347.
Thomas Jr RC, Beldia III PD, Campos WL, Santos MD. 2013. Resolving the identity of larval fishes, Dulong, in the Verde Island Passages. Philippines. Phil J of Nat 18: 29-36.

Tjakrawidjaja AH. 2002. Jenis ikan air tawar dari Manggarai, Flores, dengan variasi aspek limnologinya. J Iktiologi Indones 2 (2): 15-22.

Usman MY. 2016. Analisis Variasi Genetik Ikan Penja Indigenous Perairan Polewali Mandar Sulawesi Barat dan Ikan Nike (Awaous sp.) Indigenous Perairan Gorontalo. [Thesis]. UIN Alauddin Makassar, Makassar. [Indonesian]

Valade P, Lord C, Grondin H, Bosc P, Taillebois L, Iida M, Tsukamoto K, Keith P. 2009. Early life history and description of larval stages of an amphidromous goby, Sicyopterus lagocephalus (Gobioidei: Sicydiinae). Cybium 33 (4): 309-319.

Viswambharan D, Pavan-Kumar A, Singh DP, Jaiswar AK, Chakraborty SK, Nair JR, Lakra WS. 2013. DNA barcoding of gobiid fishes (Perciformes, Gobioidei). Mitochondrial DNA 26 (1): 15-19.

Wang ZD, Liao J, Huang CQ, Long SS, Zhang S, Guo YS, Liu L, Liu CW. 2017. Significant genetic differentiation of Gobiopterus lacustris, a newly recorded transparent goby in China. Mitochondrial DNA Part A: 1-7. DOI: 10.1080/24701394.2017.1357712.

Watanabe S, Iida M, Hagihara S, Endo H, Matsuura K, Tsukamoto K. 2011. First collection of amphidromous goby post-larvae of Sicyopterus japonicus in the ocean off Shikoku, Japan. Cybium 35 (4): 371-379.

Watson RE. 2008. A new species of Stiphodon from southern Sumatra (Pisces: Gobioidei: Sicydiinae). Zootaxa 1715: 43-56.

Yamasaki N, Kondo M, Maeda K, Tachihara K. 2011. Reproductive biology of three amphidromous gobies, Sicyopterus japonicus, Awaous melanocephalus, and Stenogobius sp., on Okinawa Island. Cybium 35 (4): 345-360.

Yokoo T, Kanou K, Moteki M, Kohno H, Tongnunui P, Kurokura H. 2011. Assemblage structures and spatial distributions of small gobioid fishes in a mangrove estuary, southern Thailand. Fish Sci 78: 237247. 